One is led to suspect that a teacher of English can hope to find only the superficial deficiencies in scientific English unless he learns more about the subject-matter. Perhaps $\mathrm{Mr}$. Kirkman is right after all in passing responsibility to the science teachers because most English teachers cannot bear it. But the scientist 's task is so often rendered well. nigh impossible by English teachers who inoculate pupils interested in science with a distaste, or at least a disclain, for the subject known as 'English'.

1 Kirkmin. A. J., Nature, 196. so- (1962).

\title{
OBITUARIES
}

\section{Dr. P. Rosbaud}

With the death on January 28 of Dr. Paul Rosbaud, at the age of sixty-six, one of the most lovable personalities in the world of science has passed away. He was not an active research scientist but was engaged in scientific publication. There cannot be many conternporary authors of scientific books who have not met him some time. He was friends with many leading scientists, mainly physicists and ehemists, and to some of them he was very close.

Born in Austria, he studied chemistry in Germany. Early in the 1930's he joined the big scientific publishing firm of Springer in Berlin as scientific editor, and there he began his fruitful publishing activities. Most of the important standard works in physics and chemistry published by this firm at the time must havo passed through his hands, and he was undoubtedly responsible for the writing of many. One of his most fateful activities was in 1938 when, after a telephone call from Prof. O. Hahn, he decided to have a paper published in Die Naturwissenschaften doseribing Hahn's discovery of nuclear fission. Thus this important fact was made known to the world shortly before the War.

In 1933, the Nazi period began, which he loathod from the very beginning. Shortly bofore the Second World War he had to send his wife out of Germany - she went to England as a refugee-but Rosbaud stayed in Berlin. $\mathrm{He}_{e}$ did not want to take one of tho fow posts then available to refugees. His office in Berlin becamo a meeting place for dissident scientists. $\mathrm{He}$ was always ready to help as much as he could those in trouble. During the War he was in constant danger of his life, owing to his manifold anti-Nazi activities; but he judged the Nazi police correctly: it was more cruel than intelligent. In the middle of the War he secured the release of two French scientists from a prisoner of war camp for "the purpose of translating. ¿ scientific book into French" (after obtaining JoliotCurie's consent that they would not be accused of collaboration after the War).

When the War ended, all the Allies knew his worth, and several Powers tried to get him. He wanted to go to England and was flown there. England bocame the country of his adoption and he loved it. Soon he began his publishing activities again. First, ho was partnor of a now scientifie publishing house but later he made himself independent, working as a free lance. Ho was scientific adviser to many big publishing firms throughout the world, modiating between author and publisher. His contact with prospective authors was always personal and this enabled him to be uniquely up to date in the developments of seience. In his small unpretentious office in London, S.W.1, with the kind landlady who was always ready with a cup of tea for the visitor, everyone must have folt at ease. His intelligonce, vividness and dry humour won the heart of everyone of good will. Ho was tolerant of every honest opinion but very intolerant of injustice, underhandednoss and so on.

In 1961 he was awarded the Tate Medal of the American. Institute of Physics for his services to science.

The post-war development of scionce was not entirely to his liking, and he worried a lot about it. $\mathrm{H}_{\Theta}$ did not like the alliance science had made with military authorities. Nor was the pretentious scale on which science was to be furthered quite to his taste, and he disliked the attitude that sponsored it. He saw the danger involved when science became too much mixed up with the intorest, of power or more material advantage.

In September 1962 he was frequently seell at the Pugwash Conferences in London (in which he nominally did not participate) discussing the world's problems with the delegates-lively as evor. $H_{\theta}$ fell ill in November. It turned out to bo leukxmia. Up to the last he thought of his friends. He died peacefully on January 28.

\section{W. HeIthen}

\section{Prof. N. R. Sen}

Nrkhil Ranjan Sen, who retired in 1959 ws (xhosh professor of applied mathematics at the University of Calcutta, after holding the chair for thirty-five years. died on January 13. He was honorary research professor at the Indian Association for the Cultivation of Science. Calcutta, at the time of his death.

Son of Shri Kalimohan Sen and Shrimati Bidhumukhi Devi, he was born on May 23, 1894. He was educated at, Dacca Collegiate School, Rajshahi School and Rajshahi College. Later he studied in Presideney College, Calcutta, and at the University of Calcutta, and he took his M.Se. degree in 1916, and D.Se. in 1921. Afterwards ho proceeded to Germany, where he worked with Prof. Max Von Laue. Shortly after returning to India he was appointed Ghosh professor in the University of Calcutta, where he worked ceaselessly to create a school of research in applied mathematies which in the courso of years sproad its influence in all parts of India.

His researches embraced several fiolds. He did interest. ing work on some intricate problems on spherical harmonies early in his career. In the early 'thirties he worked on wave mechanics, including Dirac's relativistic equations. Ho also worked on cosmological problems. Later he turned to relativistic effocts in stellar bodies and also (a littlo after the advent of Bethe's law of energy generation) to the problems of stellar constitution. During the 'fifties ho started working on turbulence and other problems of fluid mechanies.

'To his students and colleagues Sen was a model of single-minded devotion to work, and the team of enthusiastic toachers which he built up in his departmont in Calcutta was inspired by his exemplary character. His weekly sominars, which attracted persons from difforont, institutions, worked as a powerful force and pioneered a new spirit of research and study. One would also often see him on holidays holding small study groups in his houso, squatting on a mat, reminiscent of an anciont Indian teacher with his disciples.

Ho was greatly interested in the problems of toaching. mathematics at school-level, especially in relation to the teaching of higher mathematics. In the 'thirtios he started a small laboratory for numerical computation for his M.Se. students. For some years before his rotirement he was working to set up a small hydrodvnamic laboratory with a flume and a wind tunnel.

Ho was the fountain-head of inspiration of the Calcutta Mathematical Society. With the help of hardworking editorial secretaries he did his bost to raise the standard of the Bulletin of the Society.

Though essontially of retiring temperament and averse to committee work, he responded to the demands of the country and served on various committees and advisory bodies all over India.
S. N. Bosw: 